\title{
Analisis Determinan Lingkungan Kerja Terhadap Kinerja Tenaga Perawat Di Rumah Sakit Umum Bahteramas Provinsi Sulawesi Tenggara
}

\section{Determinants Analysis of the Work Environment on Nurses Performance at Bahteramas General Hospital, Southeast Sulawesi Province}

\author{
Rania Fatrizza Pritami ${ }^{1}$, Marheni Fadillah $\operatorname{Harun}^{1}$, Fitri Kurniawati ${ }^{1}, \operatorname{Irman}_{\text {Idrus }}^{2}$, (D) \\ ${ }^{1}$ Jurusan Administrasi Rumah Sakit, STIKES Pelita Ibu, Kendari 93231- Sulawesi Tenggara, Indonesia \\ ${ }^{2}$ Jurusan Farmasi, STIKES Pelita Ibu, Kendari 93231- Sulawesi Tenggara, Indonesia \\ *Corresponding author: irmanidrus80@gmail.com
}

Received: July 28, 2021

Received in revised: August 7, 2021

Accepted: August 8, 2021

Available online: August 31, 202

\begin{abstract}
Hospitals must continue to develop in order to improve the quality of hospital services. The purpose of the study was to determine the relationship between the work environment and job satisfaction of nurses at Bahteramas Hospital, Kendari City. Quantitative research method with cross sectional study approach with relative random sampling technique. Data analysis using Chi-Square test and multiple linear regression analysis. The results showed that there was a relationship between transformational leadership and nurse job satisfaction $(p=0.001)$, structural empowerment and nurse job satisfaction $(p=0.001)$; ideal professional practice with nurse job satisfaction $(p=0.001)$; innovation with nurse job satisfaction ( $p=0.013$ ); and empirical quality with nurse job satisfaction $(p=0.017)$. The conclusion is that the determinant analysis states that there is a relationship between the work environment and job satisfaction of nurses.
\end{abstract}

Keywords: Hospital, work environment, job satisfaction.

\begin{abstract}
Abstrak
Rumah sakit harus terus berkembang dalam rangka meningkatkan mutu pelayanan rumah sakit. Tujuan penelitian untuk mengetahui hubungan lingkungan kerja dengan kepuasan kerja pera wat di RS Bahteramas Kota Kendari. Metode penelitian kuantitatif dengan pendekatan cross sectional study dengan teknik relative random sampling. Analisis data menggunakan ujiChi-Square dan analisis regresi linier berganda. Hasil penelitian menunjukkan bahwa ada hubungan antara kepemimpinan transformasional dengan kepuasan kerja perawat $(\mathrm{p}=0,001)$, pemberdayaan struktural dengan kepuasan kerja perawat $(\mathrm{p}=0,001)$; praktik profesional ideal dengan kepuasan kerja perawat $(\mathrm{p}=0,001)$; inovasi dengan kepuasan kerja perawat $(\mathrm{p}=0,013)$; dan kualitas empiris dengan kepuasan kerja pera wat $(\mathrm{p}=0,017)$. Kesimpulannya a dala $\mathrm{h}$ analisis determinan menyatakan bahwa ada hubungan antara lingkungan kerja dengan kepuasan kerja pera wat.
\end{abstract}

Kata kunci : Rumah Sakit, Lingkungan kerja, Kepuasan kerja

\section{PENDAHULUAN}

Rumah Sakit harus mampauh berinovasi untuk menghadapi persaingan sehingga peningkatan kualitas layanan sangat di perlukan. Layanan rumah sakityang berkualitas merupakan refleksi dari kinerja rumah sakit
(Rudyanto, 2012). Pada dasarnya semua rumah sakit perlu untuk mengevaluasi dan memperbaiki kinerjanya, sehingga kinerja rumah sakit dapat ditingkatkan. Salah satu faktor yang mempengaruhi kinerja organisasi adalah kinerja tim dan kinerja individu. Kinerja 
individu sangat mempengaruhi kinerja organisasi secara keseluruhan (Hasmoko, 2008). Kinerja pegawai yang baik merupakan cikal bakal dari kinerja organisasi yang baik pula. Untuk mencapai kinerja yang rumah sakit yang sesuai standar pelayanan, maka peran sumber daya rumah sakit harus dioptimalkan. Manajemen sumber daya manusia di rumah sakit memberikan manfaat yang besar kepada organisasi, tim, maupun

Individu mengatakan bahwa organisasi yang ingin berumur panjang dan sustainable, harus menempatkan SDM yang handal sebagai human capital. Salah satu sumber daya manusia yang ikut berpartisipasi penting dalam pelayanan di rumah sakit adalah perawat (Purnomo, 2016).

Perawat merupakan sangat berperan enting dalam meningkatkan kualitas layanan kesehatan, karena (Yosephus, 2012). Sumber daya manusia keperawatan merupakan faktor penting dalam melakukan pelayanan di rumah sakit, karena hampir setiap negara, hingga $80 \%$ pelayanan kesehatan diberikan oleh perawat dan $60 \%$ sumber daya manusia di rumah sakit merupakan tenaga keperawatan (Zendrato and Sri Hariyati, 2018). Perawat dalam menjalankan peran dan tanggung jawabnya, menghadapi beberapa tantangan. Dengan berbagai tantangan dan peluang seperti ini dapat menimbulkan permasalahan yang berhubungan dengan tenaga keperawatan. Menurut Wuryanto (2012), permasalahan tersebut ada kaitannya dengan kekurangan tenaga perawat, ketidakpuasan kerja dan buruknya lingkungan kerja perawat.

Penelitian Baumann (2007), menyatakan seitar $41 \%$ perawat di rumah sakit merasa tidak puas dengan pekerjaannya dan $22 \%$ berencana untuk pindah pekerjaan. Sebuah penelitian di Indonesia mengemukakan bahwa perawat di rumah sakit pemerintah mengalami kepuasan kerja rendah sebesar 55,8\% (Sari, 2019). Perawat dengan kepuasan kerja dan pola pikir positif menunjukkan produktivitas yang tinggi dan keinginan untuk berpartisipasi dalam proses keperawatan, peningkatan kepuasan dan minat kerja perawat sangat penting untuk meningkatkankualitas perawat (Susanti, 2012). Karyawan yang memiliki kepuasan kerja yang tinggi maka mereka akan dapat memberikan segenap kemampuan terbaiknya dalam menyelesaikan tugas yang diberikan, sehingga produktivitas perusahaan pun meningkat, sedangkan jika kepuasan kerja yang dimiliki karyawan sangat rendah hal tersebut dapat menurunkan motivasi, moril kerja dan kinerja karyawan itu sendiri (Diviani and Djastuti, 2015).

Rumah Sakit Umum Bahteramas merupakan satu-satunya pusat rujukan di wilayah Sulawesi Tenggara. Status Rumah Sakit Bahteramas saat ini adalah Rumah Sakit kelas B dan berfungsi sebagai Rumah Sakit Pendidikan bagi dokter dan tenaga kesehatan lainnya (Niar Rahmawati, Hasmia Naningsih dan Wahida, 2017)

Berdasarkan hasil penelitian pada tahun 2015 di Rumah Sakit Bahteramas, diperoleh kepuasan kerja perawat pada tahun 2015 sebesar $50 \%$ belum puas terhadap kebijakan, sistem intensif dan sarana dan prasarana, supervisi dan kebijakan (La ode Muhammad Yasmin, 2020). Pencapaian tersebut menunjukkan adanya gap antara data rumah sakit dengan target kepuasan provider menurut BPJS yaitu 80\% (Pabidang, 2017).

Beberapa hal yang dapat mempengaruhi tingkat kepuasan dalam suatu organisasi. Faktor psikologi karyawan berupa minat, bakat dan keterampilan seseorang dapat mempengaruhi kepuasan karyawan tersebut dalam melakukan pekerjaannya. Begitupun dengan faktor fisik karyawan berupa kondisi kesehatan dan umur karyawan (Nasution, 2017). Sedangkan dari sisi eksternal terdapat faktor sosial (terkait dengan interaksi sosial dalam organisasi), faktor finansial (gaji, tunjangan dan sebagainya) hingga lingkungan kerja seperti yang ditambahkan (Hariandja; Arief and Kautsar, 2007) juga merupakan faktor yang dapat mempengaruhi puas atau tidak puasnya seseorang dalam bekerja (Ghina, 2021). Tujuan dilakukan penelitian ini adalah untuk menganalisis hubungan lingkungan pekerjaan terhadap kepuasan kerja perawat di RS Bahteramas Kota Kendari.

\section{METODE PENELITIAN}

Jenis penelitian ini adalah survey analitik dengan pendekatan cross sectional study yaitu pengukuran variabel yang sifatnya sesaat pada suatu waktu tertentu. Penelitian ini merupakan studi korelasi untuk menghubungkan dua atau lebih variabel dalam suatu kelompok dan studi komparatif untuk membandingkan perbedaan dua atau lebih kelompok terhadap varaibel tertentu (Ilyas, 2015).

\section{HASIL DAN PEMBAHASAN}


HASIL

Penelitian dilaksanakan di Rumah Sakit Bahteramas Kota Kendari pada Bulan Juni sampai Juli 2017. Pengumpulan data dilakukan di ruangan Instalasi Rawat Inap, Instalasi Rawat Jalan, Instalasi Gawat Darurat, Instalasi Bedah Sentral, Instalasi ICU (Intensive Care Unit), dan NICU (Neonate Intensive Care Unit), melalui penyebaran kuesioner yang diisi oleh 160 perawat (Mukhtari, no date). Data yang telah dikumpulkan kemudian diinput ke komputer dan dianalisis menggunakan komputer program SPSS dengan variabel penelitian adalah lingkungan kerja yaitu transformational leadership, structural empowerment, exemplary professional practice, new knowledge, innovations and improvement, empirical quality result dan variabel kepuasan kerja.

\section{Analisis Univariat}

\section{a. Karakteristik Responden}

Hasil analisis (Tabel 1) bahwa frekuensi responden di RS Bahteramas Kota Kendari dengan usia terbanyak pada kategori 31-35 tahun (32,5\%), sebagian besar berjenis kelamin perempuan, yakni sebesar $77,5 \%$, masa kerja responden sebagian besar lebih dari 5 tahun sebesar 97,5\%, pendidikan sebagian besar perawat adalah DIII Keperawatan sebanyak 40,6\%, hal ini mempertegas bahwa semakin tinggi tingkat pendidikan seseorang maka semakin tinggi pula pertimbangan atau analisis dalam melakukan sesuatu (Tawakkal, Fajar Kurniawan, 2020). Untuk penghasilan sebagian besar perawat adalah Rp.2.500.000Rp.5.000.000-, sebanyak 76,6\%.

Tabel 1. Distribusi responden menurut karakteristik umur, jenis kelamin, masa kerja, tingkat pendidikan, dan penghasilan

\begin{tabular}{lcc}
\hline \multicolumn{1}{c}{ Variabel } & \multicolumn{2}{c}{ Jumlah } \\
\cline { 2 - 3 } Perawat & Jumlah (n) & Persen (\%) \\
Umur & 260 \\
20-25 Tahun & 41 & 1,3 \\
26-30 Tahun & 52 & 24,6 \\
31-35 Tahun & 40 & 32,5 \\
36-40 Tahun & 25 & 25 \\
>41 Tahun & & 15,6 \\
Jenis Kelamin & 36 & \\
Laki-Laki & 124 & 22,5 \\
Perempuan & \multicolumn{2}{c}{} \\
Masa Kerja & 4 & 2,4 \\
$\leq 1$ tahun & 156 & 97,5 \\
$\quad>1$ tahun & \multicolumn{2}{c}{} \\
\hline
\end{tabular}

\begin{tabular}{lcc}
\hline Tingkat Pendidikan & & \\
$\quad$ SPK & 8 & 5,0 \\
D3 Keperawatan & 65 & 40,6 \\
S1 Keperawatan & 59 & 36,9 \\
S2 & 5 & 3,1 \\
$\quad$ NERS & 23 & 14,1 \\
Penghasilan & & \\
< Rp.1.500.000 & 77 & 44,5 \\
Rp.1.500.000-Rp.2.500.000 & 30 & 17,3 \\
Rp.2.500.000-Rp.3.500.000 & 37 & 21,4 \\
> Rp.3.500.000 & 29 & 16,8 \\
\hline
\end{tabular}

\section{b. Lingkungan Kerja}

\section{1) Transformational Leadership}

Tabel 2 menunjukkan bahwa dari 160 responden, 112 responden dengan kategori kurang baik pada Transformational Leadership sebesar 23,8\%. Sementara 122 responden kategori baik dengan persentase sebesar 76,3\%. Variabel transformational leadership rata-rata $70,5 \%$ responden menjawab setuju bahwa kepala ruangan/bidang memiliki transformational leadership yang kuat. Sementara yang responden yang menyatakan tidak setuju rata-rata $15,3 \%$. Presentasi pernyataan tidak setuju tertinggi $(25,6 \%)$ adalah pada pernyataan keenam yaitu kepala ruangan membuat slogan sederhana untuk memotivasi bawahannya.

Tabel 2. Distribusi Frekuensi Transformational Leadership.

\begin{tabular}{cccc}
\hline \multirow{2}{*}{ No } & $\begin{array}{c}\text { Transformational } \\
\text { Leadership }\end{array}$ & $\begin{array}{c}\text { Jumlah } \\
(\mathbf{n})\end{array}$ & $\begin{array}{c}\text { Persen } \\
(\boldsymbol{\%})\end{array}$ \\
\hline 1 & Kurang Baik & 38 & 23,8 \\
2 & Baik & 122 & 76,3 \\
\hline & Total & $\mathbf{1 6 0}$ & $\mathbf{1 0 0}$ \\
\hline
\end{tabular}

\section{2) Structural Empowerment}

Structural empowerment adalah pemberian dukungan dan kesempatan dari pimpinan/kepala ruangan dalam melakukan pengembangan profesional melalui kebijakan dan program agar terciptanya lingkungan kerja yang positif di rumah sakit (Annisa, 2019). Adapun distribusi Structural empowerment digambarkan pada tabel dibawah ini.

Tabel 3. Distribusi Frekuensi Structural Empowerment

\begin{tabular}{cccc}
\hline No & $\begin{array}{c}\text { Structural } \\
\text { Empowerment }\end{array}$ & $\begin{array}{c}\text { Jumlah } \\
(\mathbf{n})\end{array}$ & $\begin{array}{c}\text { Persen } \\
(\boldsymbol{\%})\end{array}$ \\
\hline 1 & Kurang Baik & 28 & 17,5 \\
2 & Baik & 132 & 82,5 \\
\hline Total & $\mathbf{1 6 0}$ & $\mathbf{1 0 0}$ \\
\hline
\end{tabular}


Berdasarkan Tabel 3 menunjukkan bahwa dari 160 responden, 28 responden dengan kategori kurang baik pada structural empowerment sebesar $17,5 \%$. Sementara 28 responden structural empowerment dalam kategori baik dengan persentase sebesar $82,5 \%$.

\section{3) Exemplary Professional Practice}

Berdasarkan tabel 4 menunjukkan bahwa dari 160 responden, 31 responden dengan kategori kurang baik sebesar 19,4\%. Sementara 129 responden kategori baik dengan persentase sebesar $80,6 \%$. Point pernyataan kurang baik terbesar pada point ketiga yaitu perawat tidak setuju bahwa perawat tidak memiliki kemandirian otonomi saat melakukan tindakan keperawatan di rumah sakit Bahteramas Kota Kendari (Agung Ayu Indrasari Dewi, 2017). Perawat dapat melaksanakan tindakan pada saat DPJP tidak ditempat namun mengikuti in struksi dari dokter DPJP melalui telepon.

Variabel Exemplary Professional Practice presentase tertinggi rata-rata $59,2 \%$ responden menjawab setuju, dan presentase terendah responden menjawab sangat tidak setuju sebesar $4 \%$. Presentasi pernyataan tidak setuju tertinggi $(56,9 \%)$ adalah pada pernyataan tiga yaitu perawat tidak memiliki kemandirian (otonomi) untuk melakukan tindakan keperarawat.

Tabel 4. Distribusi Frekuensi Exemplary Professional Practice

\begin{tabular}{clcc}
\hline No & $\begin{array}{c}\text { Exemplary } \\
\text { Professional } \\
\text { Practice }\end{array}$ & $\begin{array}{c}\text { Jumlah } \\
(\mathbf{n})\end{array}$ & $\begin{array}{c}\text { Persen } \\
(\%)\end{array}$ \\
\hline 1 & Kurang Baik & 31 & 19,4 \\
2 & Baik & 129 & 80,6 \\
\hline Total & & $\mathbf{1 6 0}$ & $\mathbf{1 0 0}$ \\
\hline
\end{tabular}

\section{4) New Knowledge, Innovations \& \\ Improvements}

Berdasarkan Tabel 5 menunjukkan bahwa dari 160 responden, 36 responden dengan kategori kurang sebesar 22,5\%. Sementara 124 responden kategori cukup dengan persentase sebesar 77,5\%. Variabel New Knowledge, Innovations \& Improvements presentase tertinggi rata-rata $62,5 \%$ responden menjawab setuju, dan presentase terendah responden menjawab sangat tidak setuju sebesar 3,3\%. Presentasi tidak setuju yang tertinggi adalah pada pernyataan satu yaitu rumah sakit melakukan sistem perbaikan mutu secara terus menerus. Dalam hal ini penyataan tidak setuju pada point rumah sakit melakukan perbaikan mutu secara terus menerus artinya rumah sakit Bahteramas belum maksimal dalam evaluasi guna perbaikan mutu rumah sakit, hal ini dikarenakan perawat belum melihat output dari perbaikan mutu secara berkelanjutan yang dilakukan oleh pihak rumah sakit (Putri, 2009).

Tabel 5. Distribusi Frekuensi New Knowledge, Innovations \& Improvements

\begin{tabular}{clcc}
\hline No & $\begin{array}{c}\text { New Knowledge, } \\
\text { Innovations \& } \\
\text { Improvements }\end{array}$ & $\begin{array}{c}\text { Jumlah } \\
(\mathbf{n})\end{array}$ & $\begin{array}{c}\text { Persen } \\
(\%)\end{array}$ \\
\hline $1 \quad$ Kurang & 36 & 22,5 \\
2 & Cukup & 124 & 77,5 \\
\hline Total & $\mathbf{1 6 0}$ & $\mathbf{1 0 0}$ \\
\hline
\end{tabular}

\section{5) Empirical Quality Result}

Tabel 6 menunjukkan bahwa dari 160 responden 5 responden dengan kategori kurang baik sebesar $3,1 \%$. Sementara 155 responden kategori baik dengan persentase sebesar 96,9\%. Pada kategori baik tertinggi terdapat pada pernyataan pertama yaitu lingkungan kerja memprioritaskan budaya keselamatan kerja dalam pelayanan dan tindakan yang dilakukan tenaga kesehatan di rumah sakit Bahteramas kota kendari (Mardhiah Afrini, 2017). Sementasa tidak setuju tertinggi yaitu pada pernyataan kedua yaitu kepala ruangan melakukan pengawasan saat perawat melakukan tindakan (Warsito, 2006).

Variabel Empirical Quality Result presentase tertinggi rata-rata $62,5 \%$ responden menjawab setuju, dan presentase terendah responden menjawab sangat tidak setuju sebesar $1,9 \%$. Presentase tidak setuju tertinggi adalah pada pernyataan dua yaitu kepala ruangan melakukan pengawasan saat perawat melakukan tindakan. Hal ini berarti kepala ruangan tidak selalu ada saat perawat pelaksana melakukan tindakan asuhan keperawatan yang seharusnya kepala ruangan selalu ada untuk mengontrol pada saat perawat pelaksana melakukan tindakan asuhan keperawatan kepada pasien (Pribadi, 2009).

Tabel 6. Distribusi Frekuensi Empirical Quality Result

\begin{tabular}{clcc}
\hline No & $\begin{array}{c}\text { Empirical } \\
\text { Quality Result }\end{array}$ & $\begin{array}{c}\text { Jumlah } \\
(\mathbf{n})\end{array}$ & $\begin{array}{c}\text { Persen } \\
(\%)\end{array}$ \\
\hline 1 & Kurang Baik & 5 & 3,1 \\
2 & Baik & 155 & 96,9 \\
\hline Total & & $\mathbf{1 6 0}$ & $\mathbf{1 0 0}$ \\
\hline
\end{tabular}




\section{c. Kepuasan Kerja}

\section{1) Transformational Leadership}

Tabel 7 menunjukkan bahwa dari 160 responden, 112 responden dengan kategori kurang baik pada Transformational Leadership sebesar 23,8\%. Sementara 122 responden kategori baik dengan persentase sebesar $76,3 \%$.

Tabel 7. Distribusi Frekuensi

Transformational Leadership

\begin{tabular}{clcc}
\hline No. & $\begin{array}{c}\text { Transformational } \\
\text { Leadership }\end{array}$ & $\begin{array}{c}\text { Jumlah } \\
(\mathbf{n})\end{array}$ & $\begin{array}{c}\text { Persen } \\
(\mathbf{\%})\end{array}$ \\
\hline 1 & Kurang Baik & 38 & 23,8 \\
2 & Baik & 122 & 76,3 \\
\hline Total & & $\mathbf{1 6 0}$ & $\mathbf{1 0 0}$ \\
\hline
\end{tabular}

\section{2) Structural Empowerment}

Berdasarkan Tabel 8 menunjukkan bahwa dari 160 responden, 28 responden dengan kategori kurang baik pada structural empowerment sebesar $17,5 \%$. Sementara 28 responden structural empowerment dalam kategori baik dengan persentase sebesar $82,5 \%$.

Tabel 8. Distribusi Frekuensi Structural

\begin{tabular}{clcc}
\multicolumn{4}{c}{ Empowerment } \\
\hline \multirow{2}{*}{ No. } & $\begin{array}{c}\text { Structural } \\
\text { Empowerment }\end{array}$ & $\begin{array}{c}\text { Jumlah } \\
(\mathbf{n})\end{array}$ & $\begin{array}{c}\text { Persen } \\
(\%)\end{array}$ \\
\hline 1 & Kurang Baik & 28 & 17,5 \\
2 & Baik & 132 & 82,5 \\
\hline Total & & $\mathbf{1 6 0}$ & $\mathbf{1 0 0}$ \\
\hline
\end{tabular}

\section{3) Exemplary Professional Practic}

Tabel 9. Distribusi Frekuensi Exemplary Professional Practice

\begin{tabular}{cccc}
\hline No & $\begin{array}{c}\text { Exemplary } \\
\text { Professional } \\
\text { Practice }\end{array}$ & $\begin{array}{c}\text { Jumlah } \\
(\mathbf{n})\end{array}$ & $\begin{array}{c}\text { Persen } \\
(\boldsymbol{\%})\end{array}$ \\
\hline 1 & Kurang Baik & 31 & 19,4 \\
2 & Baik & 129 & 80,6 \\
\hline Total & & $\mathbf{1 6 0}$ & $\mathbf{1 0 0}$ \\
\hline
\end{tabular}

Tabel 9 menunjukkan bahwa dari 160 responden, 31 responden dengan kategori kurang baik sebesar 19,4\%. Sementara 129 responden kategori baik dengan persentase sebesar $80,6 \%$. Point pernyataan kurang baik terbesar pada point ketiga yaitu perawat tidak setuju bahwa perawat tidak memiliki kemandirian otonomi saat melakukan tindakan keperawatan di rumah sakit Bahteramas Kota Kendari. Perawat dapat melaksanakan tindakan pada saat DPJP tidak ditempat namun mengikuti instruksi dari dokter DPJP melalui telepon (Agung Ayu Indrasari Dewi, 2017).

\section{4) New Knowledge, Innovations \&} Improvements

Berdasarkan Tabel 10 menunjukkan bahwa dari 160 responden, 36 responden dengan kategori kurang sebesar 22,5\%. Sementara 124 responden kategori cukup dengan persentase sebesar $77,5 \%$.

Tabel 10. Distribusi Frekuensi New Knowledge, Innovations \& Improvements

\begin{tabular}{cccc}
\hline No. & $\begin{array}{c}\text { New } \\
\text { Knowledge, } \\
\text { Innovations \& } \\
\text { Improvements }\end{array}$ & $\begin{array}{c}\text { Jumlah } \\
\text { (n) }\end{array}$ & $\begin{array}{c}\text { Persen } \\
(\boldsymbol{\%})\end{array}$ \\
\hline 1 & Kurang & 36 & 22,5 \\
2 & Cukup & 124 & 77,5 \\
\hline Total & & $\mathbf{1 6 0}$ & $\mathbf{1 0 0}$ \\
\hline
\end{tabular}

5) Empirical Quality Result

Berdasarkan Tabel 11 menunjukkan bahwa dari 160 responden 5 responden dengan kategori kurang baik sebesar 3,1\%. Sementara 155 responden kategori baik dengan persentase sebesar 96,9\%. Pada kategori baik tertinggi terdapat pada pernyataan pertama yaitu lingkungan kerja memprioritaskan budaya keselamatan kerja dalam pelayanan dan tindakan yang dilakukan tenaga kesehatan di rumah sakit Bahteramas kota kendari. Sementasa tidak setuju tertinggi yaitu pada pernyataan kedua yaitu kepala ruangan melakukan pengawasan saat perawat melakukan tindakan (Agung Ayu Indrasari Dewi, 2017)

Tabel 11. Distribusi Frekuensi Empirical Quality Result

\begin{tabular}{clcc}
\hline No. & $\begin{array}{c}\text { Empirical } \\
\text { Quality Result }\end{array}$ & $\begin{array}{c}\text { Jumlah } \\
(\mathbf{n})\end{array}$ & $\begin{array}{c}\text { Persen } \\
(\%)\end{array}$ \\
\hline 1 & Kurang Baik & 5 & 3,1 \\
2 & Baik & 155 & 96,9 \\
\hline Total & & $\mathbf{1 6 0}$ & $\mathbf{1 0 0}$ \\
\hline
\end{tabular}

Tabel 12. Distribusi Frekuensi VariabelVariabel Lingkungan

\begin{tabular}{clcc}
\hline No & \multicolumn{1}{c}{$\begin{array}{c}\text { Variabel } \\
\text { Lingkungan Kerja }\end{array}$} & $\begin{array}{c}\text { Jumlah } \\
(\mathbf{n})\end{array}$ & $\begin{array}{c}\text { Persen } \\
(\boldsymbol{\%})\end{array}$ \\
\hline 1 & Transformational & & \\
& Leadership & 38 & 23,8 \\
& $\quad$ Kurang Baik & 122 & 76,3 \\
& $\quad$ Puas & & \\
\multirow{2}{*}{2} & Structural & & \\
& Empowerment & 28 & 17,5 \\
\hline
\end{tabular}




\begin{tabular}{|c|c|c|c|}
\hline \multirow{6}{*}{3} & Kurang Baik & 132 & 82,5 \\
\hline & Baik & & \\
\hline & Exemplary & & \\
\hline & Professional Practice & 31 & 19,4 \\
\hline & Kurang Baik & 129 & 80,6 \\
\hline & Baik & & \\
\hline \multirow[t]{4}{*}{4} & New Knowledge, & & \\
\hline & Innovations \&Improve & 36 & 22,5 \\
\hline & ment & 124 & 77,5 \\
\hline & $\begin{array}{l}\text { Kurang Baik } \\
\text { Baik }\end{array}$ & & \\
\hline \multirow[t]{5}{*}{5} & Empirical Quality & 36 & 22,5 \\
\hline & Result & 124 & 77,5 \\
\hline & Kurang & & \\
\hline & Cukup & & \\
\hline & Total rata-rata & 80 & 50 \\
\hline
\end{tabular}

Tabel 12 diatas dapat disimpulkan bahwa variabel lingkungan kerja dengan kategori baik tertinggi adalah variabel Structural empowerment $(82,4 \%)$, sementara yang tertinggi dalam kategori kurang baik adalah variabel transformational leadership (23,8\%).

\section{d. Hubungan Transformational Leadership dengan Kepuasan Kerja Perawat}

Tabel 13 menunjukkan bahwa dari 160 responden yang diteliti, terdapat 38 responden dengan transformational leadership kurang baik memiliki kepuasan kerja yang rendah yaitu sebanyak 16 orang $(42,1 \%)$ dan 22 orang $(57,9 \%)$ yang memiliki kepuasan kerja yang tinggi. Sebaliknya dari 122 responden dengan transformational leadership yang baik memiliki kepuasan kerja yang tinggi yaitu sebanyak 95 orang $(77,9 \%)$ sedangkan 27 orang $(22,1 \%)$ yang memiliki kepuasan kerja yang rendah. Pada Tabel 15, juga menunjukkan bahwa hasil uji chi square diperoleh nilai $\mathrm{p}=0,015<\alpha=0,05$, maka hipotesis diterima. Hal ini menunjukkan bahwa ada hubungan transformational leadership dengan kepuasan perawat di RS Bahteramas Kota Kendari Tahun 2017.

\section{e. Hubungan Structural Empowerment dengan Kepuasan Kerja.}

Tabel 14 menunjukkan bahwa dari 160 responden yang diteliti, terdapat 28 responden dengan structural empowerment kurang baik memiliki kepuasan kerja yang rendah yaitu sebanyak 12 orang $(42,9 \%)$ dan 16 orang $(57,1 \%)$ yang memiliki kepuasan kerja yang tinggi. Sebaliknya dari 132 responden dengan structural empowerment yang baik memiliki kepuasan kerja yang tinggi yaitu sebanyak 101 orang $(76,5 \%)$ sedangkan 31 orang $(23,5 \%)$ yang memiliki kepuasan kerja yang rendah.
Pada tabel 18, juga menunjukkan bahwa hasil uji chi square diperoleh nilai $p=0,036<\alpha=0,05$, maka hipotesis diterima. Hal ini menunjukkan bahwa ada hubungan structural empowerment dengan kepuasan perawat di RS Bahteramas Kota Kendari Tahun 2017.

\section{f. Hubungan Examplary Professional Practice dengan Kepuasan Kerja Perawat}

Tabel 15 menunjukkan bahwa dari 160 responden yang diteliti, terdapat 31 responden dengan Examplary Professional Practice kurang baik memiliki kepuasan kerja yang rendah yaitu sebanyak 20 orang $(64,5 \%)$ dan 11 orang $(35,5 \%)$ yang memiliki kepuasan kerja yang tinggi (Hasmoko, 2008). Sebaliknya dari 129 responden dengan exemplary professional practice yang baik memiliki kepuasan kerja yang tinggi yaitu sebanyak 106 orang $(82,2 \%)$ sedangkan 23 orang $(17,8 \%)$ yang memiliki kepuasan kerja yang rendah. Padatabel 19, juga menunjukkan bahwa hasil uji chi square diperoleh nilai $p=0,000<\alpha=0,05$, maka hipotesis diterima. Hal ini menunjukkan bahwa ada hubungan Examplary Professional Practice dengan kepuasan perawat di RS Bahteramas Kota Kendari Tahun 2017.

\section{g. Hubungan New Knowledge, Innovations \& Improvements dengan Kepuasan Kerja Perawat}

Tabel 16 menunjukkan bahwa dari 160 responden yang diteliti, terdapat 36 responden dengan new knowledge, innovations \& improvements kurang memiliki kepuasan kerja yang rendah yaitu sebanyak 15 orang $(41,7 \%)$ dan 21 orang $(58,3 \%)$ yang memiliki kepuasan kerja yang tinggi. Sebaliknya dari 124 responden dengan new knowledge, innovations \& improvements yang cukup memiliki kepuasan kerja yang tinggi yaitu sebanyak 96 orang $(77,4 \%)$ sedangkan 28 orang $(22,6 \%)$ yang memiliki kepuasan kerja yang rendah. Pada Tabel 18, juga menunjukkan bahwa hasil uji chi square diperoleh nilai $\mathrm{p}=0,023<\alpha=0,05$, maka hipotesis diterima. Hal ini menunjukkan bahwa ada hubungan new knowledge, innovations \& improvements dengan kepuasan perawat di RS Bahteramas Kota Kendari Tahun 2017. 
Tabel 13. Hubungan Transformational Leadership dengan Kepuasan Kerja.

\begin{tabular}{cccccccc}
\hline & \multicolumn{4}{c}{ Kepuasan Kerja } & \multirow{2}{*}{ Total } & \multirow{2}{*}{ P } \\
\cline { 2 - 7 } Transformational Leadership & \multicolumn{2}{c}{ Rendah } & \multicolumn{2}{c}{ Tinggi } & & \\
\cline { 2 - 7 } & $\mathrm{n}$ & $\%$ & $\mathrm{n}$ & $\%$ & $\mathrm{n}$ & $\%$ & \\
\hline Kurang Baik & 16 & 42,1 & 22 & 57,9 & 38 & 100 & \\
Baik & 27 & 22,1 & 95 & 77,9 & 122 & 100 & 0,015 \\
\hline Total & 43 & 26,9 & 117 & 73,1 & 160 & 100 & \\
\hline
\end{tabular}

Tabel 14. Hubungan Structural Empowerment dengan Kepuasan Kerja

\begin{tabular}{|c|c|c|c|c|c|c|c|}
\hline \multirow{3}{*}{ Structural Empowerment } & \multicolumn{4}{|c|}{ Kepuasan Kerja } & \multirow{2}{*}{\multicolumn{2}{|c|}{ Total }} & \multirow{3}{*}{$\mathbf{P}$} \\
\hline & \multicolumn{2}{|c|}{ Rendah } & \multicolumn{2}{|c|}{ Tinggi } & & & \\
\hline & $\mathrm{n}$ & $\%$ & $\mathrm{n}$ & $\%$ & $\mathrm{n}$ & $\%$ & \\
\hline Kurang Baik & 12 & 42,9 & 16 & 57,1 & 28 & 100 & \\
\hline Baik & 31 & 23,5 & 101 & 76,5 & 132 & 100 & 0,036 \\
\hline Total & 43 & 26,9 & 117 & 73,1 & 160 & 100 & \\
\hline
\end{tabular}

Tabel 15. Hubungan Examplary Professional Practice dengan Kepuasan Kerja Perawat

\begin{tabular}{|c|c|c|c|c|c|c|c|}
\hline \multirow{3}{*}{ Examplary Professional Practice } & \multicolumn{4}{|c|}{ Kepuasan Kerja } & \multirow{2}{*}{\multicolumn{2}{|c|}{ Total }} & \multirow{3}{*}{$\mathbf{P}$} \\
\hline & \multicolumn{2}{|c|}{ Rendah } & \multicolumn{2}{|c|}{ Tinggi } & & & \\
\hline & $\mathrm{n}$ & $\%$ & $\mathrm{n}$ & $\%$ & $\mathrm{n}$ & $\%$ & \\
\hline Kurang Baik & 20 & 64,5 & 11 & 35,5 & 31 & 100 & \\
\hline Baik & 23 & 17,8 & 106 & 82,2 & 129 & 100 & 0,001 \\
\hline Total & 43 & 26,9 & 117 & 73,1 & 160 & 100 & \\
\hline
\end{tabular}

Tabel 16. Hubungan New Knowledge, Innovations \& Improvements dengan Kepuasan Kerja

\begin{tabular}{|c|c|c|c|c|c|c|c|}
\hline \multirow{3}{*}{ New Knowledge, Innovations \& Improvements } & \multicolumn{4}{|c|}{ Kepuasan Kerja } & \multirow{2}{*}{\multicolumn{2}{|c|}{ Total }} & \multirow{3}{*}{$\mathbf{P}$} \\
\hline & \multicolumn{2}{|c|}{ Rendah } & \multicolumn{2}{|c|}{ Tinggi } & & & \\
\hline & $\mathrm{n}$ & $\%$ & $\mathrm{n}$ & $\%$ & $\mathrm{n}$ & $\%$ & \\
\hline Kurang & 15 & 41,7 & 21 & 58,3 & 36 & 100 & \\
\hline Cukup & 28 & 22,6 & 96 & 77,4 & 124 & 100 & 0,023 \\
\hline Total & 43 & 26,9 & 117 & 73,1 & 160 & 100 & \\
\hline
\end{tabular}

Tabel 17. Hubungan Empirical Quality Result dengan Kepuasan Kerja

\begin{tabular}{|c|c|c|c|c|c|c|c|}
\hline \multirow{3}{*}{ Empirical Quality Result } & \multicolumn{4}{|c|}{ Kepuasan Kerja } & \multirow{2}{*}{\multicolumn{2}{|c|}{ Total }} & \multirow{3}{*}{$\mathbf{P}$} \\
\hline & \multicolumn{2}{|c|}{ Rendah } & \multicolumn{2}{|c|}{ Tinggi } & & & \\
\hline & $\mathrm{n}$ & $\%$ & $\mathrm{n}$ & $\%$ & $\mathrm{n}$ & $\%$ & \\
\hline Kurang & 17 & 47,2 & 19 & 52,8 & 36 & 100 & \\
\hline Cukup & 26 & 21,0 & 98 & 79,0 & 124 & 100 & 0,002 \\
\hline Total & 43 & 26,9 & 117 & 73,1 & 160 & 100 & \\
\hline
\end{tabular}

Tabel 18. Faktor yang Berhubungan dengan Kepuasan Perawat

\begin{tabular}{lcccc}
\hline \multicolumn{1}{c}{ Variabel } & B & Wald & P & Exp (B) \\
\hline Transforamational Leadership & 1,212 & 12,323 & 0,001 & 0,054 \\
Structural Empowerment & 1,341 & 13,341 & 0,001 & 0,168 \\
Exemplary Professional Practice & 2,062 & 19,027 & 0,001 & 0,127 \\
New Knowledge, Innovations \& Improvement & 1,232 & 4,564 & 0,013 & 0,132 \\
Empirical Quality Result & 1,112 & 5,739 & 0,017 & 0,329 \\
\hline Constant & $\mathbf{6 , 9 5 9}$ & $\mathbf{5 4 . 9 9 4}$ & $\mathbf{0 , 0 4 9}$ & $\mathbf{1 , 2 9 6}$ \\
\hline
\end{tabular}

\section{h. Hubungan Empirical Quality Result dengan Kepuasan Kerja}

Tabel 17 menunjukkan bahwa dari 160 responden yang diteliti, terdapat 36 responden dengan empirical quality result kurang memiliki kepuasan kerja yang rendah yaitu sebanyak 17 orang $(47,2 \%)$ dan 19 orang $(52,8 \%)$ yang memiliki kepuasan kerja yang tinggi. Sebaliknya dari 124 responden dengan empirical quality result yang cukup memiliki kepuasan kerja yang tinggi yaitu sebanyak 98 orang $(79,0 \%)$ sedangkan 26 orang $(21,0 \%)$ 
yang memiliki kepuasan kerja yang rendah (Chasanah, 2008). Pada tabel 21, juga menunjukkan bahwa hasil uji chi square diperoleh nilai $\mathrm{p}=0,002<\alpha=0,05$, maka hipotesis diterima (Ayu, 2018). Hal ini menunjukkan bahwa ada hubungan empirical quality result dengan kepuasan perawat di RS Bahteramas Kota Kendari Tahun 2017.

\section{Analisis Multivariat}

Tabel 18 menunjukkan bahwa hasil uji statistik regresi logistik berganda, variabel lingkungan kerjaberpengaruh dengan kepuasan kerja perawat di Rumah Sakit Bahteramas Kota Kendari (nilai P 0,001; 0,001; 0,001, 0,013, $0,017<0,05)$. Tabel 22 , juga menunjukkan bahwa lingkungan kerja memberikan pengaruh terhadap kepuasan kerja di RS Bahtermas yaitu masing-masing, 2,212, 1,341, 2,062, 1,232, 1,112 walaupun examplary professional practice memiliki nilai B lebih besar (Yunda, 2019). Hal ini menunjukkan bahwa examplary professional practice yang tinggi dengan nilai $(\mathrm{B}=2,062)$ akan meningkatkan kepuasan kerja perawat sebesar 0,127 kali (Yunda, 2019).

\section{PEMBAHASAN}

Hasil penelitian dengan meninjau teori-teori terkait berdasarkan literatur dan penelitianpenelitian sebelumnya yang berhubungan dengan sejumlah variabel yang diteliti. Pembahasan juga menggambarkan implikasi penelitian terhadap pelayanan keperawatan dan keterbatasan selama pelaksanaan penelitian (Prakarsa, 2017). Pembahasan lebih difokuskan pada analisis hubungan antara variabel independen lingkungan kerja yaitu transformational leadership, structural leadership, exemplary professional practice, new knowledge, innovations\&improvement, dan empirical quality result terhadap variabel dependen kepuasan kerja perawat.

\section{Hubungan Transformational Leadership terhadap Kepuasan Kerja}

Upaya untuk terciptanya lingkungan kerja yang positif, International Council of Nursing (ICN) merekomendasikan kepada rumah sakit yang ada di seluruh dunia untuk menerapkan kriteria The Magnet Recognition Program yang dikembangkan oleh Amerikan Nurses Credentialing Center (ANCC) yang terdiri atas 5 komponen, salah satu dari komponen tersebut adalah transformational leadership yang diterapkan untuk kebutuhan pemenuhan kepuasan perawat (Lamidi, 2009).

Berdasarkan dari hasil analisis dari pengaruh dalam menerapkan transformational leadership terhadap kepuasan kerja perawat, ditemukan bahwa terdapat pengaruh yang sangat signifikan dari transformational leadership terhadap kepuasan kerja perawat dengan pembuktian pemerolehan nilai $\mathrm{p} 0.005$ $<0.05$ (Fayzhall, Asbari and Purwanto, 2020).

Transformational leadership sering dikaitkan dengan gaya kepemimpinan yang umumnya dimiliki oleh pimpinan (top management) (Setiawan, 2013). Hasil penelitian ini dapat menerangkan bahwa transformational leadership juga dapat diperankan oleh kepala ruangan. Sebagai pemimpin yang berdampak langsung terhadap peningkatan soft skill dalam kinerja kerja perawat, ketua diharapkan dapat menggunakan pola kepemimpinan yang positif; $\mathrm{H}$. kepemimpinan transformatif.

\section{Hubungan Structural Empowerment terhadap Kepuasan Kerja \\ Hasil analisis pengaruh structural} empowerment terhadap kepuasan kerja perawat ditemukan bahwa ada pengaruh yang signifikan dari structural empowerment terhadap kepuasan kerja perawat dengan nilai $\mathrm{p}=0.030$ $<$ 0.05. Pemberdayaan structural dan pemberdayaan psikologis memiliki pengaruh yang positif terhadap kepuasan kerja. Khususnyaterhadap staf perawat merasa bahwa pemberdayaan structural ditempat kerja mereka menghasilkan tingkat yang lebih tinggi dari pemberdayaan psikologis dalam merasakan enjoy dalam bekerja, keyakinan yang lebih tinggi, otonomi yang lebih besar dan juga keyakinan yang lebih besar bahwa para pekerja dapat memberikan dampak pada pekerjaannya (Devi, 2017).

Penelitian ini berbeda dengan penelitian yang dilakukan oleh (Lodjo, 2013) tentang pelatihan, pemberdayaan, dan efikasi dini terhadap kepuasan kerja mengatakan bahwa tidak ada pengaruh signifikan terhadap pemberdayaan dengan kepuasan kinerja karyawan. Amerikan Nurses Credentialing Center (ANCC) menyusun indikator-indikator yang menjadi kekuatan terciptanya structural empowerment yang baik dalam suatu lingkungan kerja karyawan khususnya tenaga keperawatan, yaitu struktur organisasi, kebijakan dan program personal, organisasi dan 
komunitas kesehatan, citra keperawatan serta pengembangan profesi (Lodjo, 2013).

Lingkungan kerja yang menyediakan akses informasi, sumber, dukungan dan kesempatan untuk belajar serta berkembang merupakan suatu pemberdayaan (empowerment). structural empowerment di RS. Bahteramas Kota Kendari dinilai sudah berjalan sangat baik. Berdasarkan hasil distribusi responden yang disebar di RS tersebut sebanyak 132 orang terhitung $82.5 \%$ yang menyatakan bahwa structural empowerment berada pada kategori baik dan 28 orang terhitung $17.5 \%$ yang menyatakan kurang baik. Namun untuk menyempurnakan variable ini maka sesuai dengan pernyataan pada kuisioner bahwa rumah sakit melakukan kerja sama dengan komunitas lain mendapat jawaban tertinggi tidak setuju dari perawat. hal ini dikarenakan perawat tidak mendapatkan manfaat dari kerja sama dengan komunitas lain, dan kurangnya program yang ditujukan untuk peningkatan kerjasama dari komunitas kesehatan maupun non kesehatan di rumah sakit tersebut (Tahsinia, 2015). Simpulan dari variabel structural empowerment rumah sakit Bahteramas Kota kendari sudah baik, perlu untuk dipertahankan dan ditingkatkan untuk meningkatkan kerjasama degan komunitas kesehatan dan non kesehatan lainnya baik diluar maupun didalam rumah sakit.

Hasil persentasi pada penelitian ini dapat disimpulkan bahwa structural empowerment perlu dipertahankan dan di tingkatkan pada kerjasama antar komunitas guna meningkatkan kepuasan kerja pada perawat, pertambahan relasi dan program pembelajaran seumur hidup dan pengembangan karir perawatan (Kurnia, 2021).

\section{Hubungan Exemplary Professional Practice terhadap Kepuasan Kerja}

Hasil analisis pengaruh exemplary professional practice terhadap kepuasan kinerja perawat ditemukan bahwa tidak ada pengaruh yang signifikan dari Exemplary Professional Practice terhadap kepuasan kerja perawat, dengan nilai $\mathrm{p}=0.035<0.05$. Hasil penelitian ini sejalan dengan penelitian sebelumnya mengemukakan bahwa hubungan professional memiliki hubungan yang signifikan antara hubungan professional terhadap kepuasan kinerja perawat (Set Xaverius Tumbelaka, 2016). Mengembangkan model praktik keperawatan profesional memungkinkan hubungan profesional antara perawat dan petugas kesehatan lainnya dalam organisasi. Hubungan ini dapat muncul melalui sistem dokumentasi perawatan, penugasan layanan, wawancara awal dan akhir, dan diskusi kasus (Achmad Masfi, 2018).

Selain itu pada indikator konsultan dan sumber informan yang dimaksud adalah konsultan atau sumber atau pakar keperawatan yang dipercaya dapat memberikan arahan atau bimbingan dalam menjalankan tindakan keperawatan yang berkualitas (Bawono and Nugraheni, 2015). Dalam hal kepuasan perawat, kepuasan kerja dalam praktik keperawatan dicapai ketika perawat merasa telah berkontribusi, merasa penting, menerima dukungan dari sumber yang ada, dan mencapai banyak hasil keperawatan (Sureskiarti and Brillianty, 2017).

Selain faktor otonomi, terdapat juga faktor perawat sebagai pendidik. Perawat memiliki peran bertanggungjawab meneruskan pendidikan dan pengembangan professional dan pemantauan standar praktek (Maria, 2020). Faktor dengan melihat persfektif pimpinan dan pengelola keperawatan, penting untuk memahami faktor, pribadi, professional dan organisasi yang secara langsung berhubungan dengan kepuasan kerja antar perawat dalam pengaturan perawatan yang tepat (Mayasari, 2009). Bagi responden, mereka menyadari bahwa peran professional dalam tindakan keperawatan sudah menjadi tanggungjawab mereka dalam bekerja., sehingga perasaan puas atau tidak puas menjadi penilaian tersendiri bagi mereka (Baihaqi and Suharnomo, 2010).

Kesimpulan dari variabel ini adalah exemplary professional practice sudah berada pada kategori baik dan perlu di pertahankan dan ditingkatkan lagi dengan perbaikan dan evaluasi secara berkala, kepala ruangan harus lebih jeli untuk melihat konflik dan memecahkannya dengan mengutamakan rasionalitas dalam memecahkan masalah pada perawat dan tenaga kesehatan lain di tiap unitnya.

\section{Hubungan New Knowledge, Innovations and Improvements terhadap kepuasan kerja}

Pada hasil analisis pengaruh new knowledge, innovations and improvements terhadap kepuasan kerja perawat ditemukan bahwa ada pengaruh yang signifikan dari new knowledge, innovations and improvements 
terhadap kepuasan kerja perawat dengan nilai $\mathrm{p}=0,014<0,05$.

Faktor yang mendorong terciptanya new knowledge, innovations and improvements di lingkungan kerja perawat dapat dilihat dari perbaikan mutu yang dijalankan. Staf keperawatan harus dilibatkan dalam perencanaan perbaikan mutu rumah sakit yang dianggap sebagai proses perbaikan sistem pemberian pelayanan keperawatan, serta dalam menumbuhkan kepuasan perawat bukanlah suatu keadaan statis namun bergantung pada pengaruh dan modifikasi dari kekuatan didalam (karakteristik pribadi) dan diluar individu (lingkungan kerja) (Adam, 2013).

Pentingnya pengakuan atau akreditasi mutu mempengaruhi berbagai pihak, antara lain: (1) Bagi rumah sakit, berguna sebagai alat negosiasi dengan pihak ketiga, perusahaan asuransi atau perusahaan. Pengelola Rumah Sakit (3) Kinerja dan akreditasi perusahaan asuransi berguna sebagai data acuan dalam pemilihan rumah sakit dan kontrak (Berliana, 2019).

Hasil penelitian ini menjelaskan bahwa persepsi perawat tentang variabel new knowledge, innovations and improvements di lingkungan kerja perawat RS Bahtermas Kota Kendari berada dalam kondisi cukup baik 77,5 $\%$ dan variabel ini signifikan mempengaruhi kepuasan kerja perawat. hal- hal yang dibutuhkan dalam menjalankan perbaikan mutu ilmu pengetahuan yang baru sangat penting bagi perawat agar menjadi motivasi untuk berinovasi dan melakukan perbaikan dari kekurangan sebelumnya. Untuk menyempurnakan variabel ini, sesuai dengan pernyataan pada kuisioner yaitu sebanyak 46 responden $(22,8 \%)$ menyatakan bahwa rumah sakit tidak melakukan perbaikan secara terus menerus. Artinya pada tingkat manajemen harus meningkatkan evaluasi untuk perbaikan mutu di rumah sakit dengan melibatkan seluruh staf keperawatan. dan menanggapi dengan serius apa yang menjadi masukan dan ide terhadap perbaikan di tiap unitnya (Baihaqi and Suharnomo, 2010).

Kesimpulan dari variabel exemplary professional practice yaitu variabel ini dikategorikan sudah baik sebanyak 77,5\%, perlu di pertahankan dan perlu ditingkatkan pada rumah sakit melakukan sistem perbaikan secara terus menerus untuk meingkatkan mutu pelayanan dir rumah sakit.

\section{Hubungan Empirical Quality}

Result terhadap Kepuasan Kerja

Hasil analisis pengaruh empirical quality result ditemukan bahwa ada pengaruh yang sangat signifikan dari empirical quality result dengan nilai $\mathrm{p}=0,001<0,05$ (Sanjaya, 2012). Penelitian ini sejalan dengan penelitian yang dilakukan oleh Aron (2015) bahwa korelasi yang positif antara kualitas pelayanan yang diberikan dengan kepuasan kerja perawat. indikator yang paling mempengaruhi kepuasan kerja adala kompensasi dan kualitas keperawatan dalam pemberian pelayanan kesehatan (Priadi, 2021).

Penelitian dengan hasil yang berbeda dilakukan oleh (Kwak and Chung, 2010) tentang empirical quality result tentang Relationship of Job Satisfaction with perceived organizational support and Quality of care among South Korean Nurses menemukan suatu persepsi perawat tentang kualitas pelayanan keperawatan tidak signifikan mempresiksi kepuasan kerja perawat. Hal tersebut disebabkan karena perawat kurang yakin bahwa pasien dapat secara mandiri mengatur kondisi mereka setelah keluar dari rumah sakit.

Hasil penelitian ini menjelaskan bahwa persepsi perawat tentang variabel empirical quality result di lingkungan kerja perawat RS Bahtermas Kota Kendari berada dalam kondisi baik 96,9\% dan variabel ini signifikan mempengaruhi kepuasan kerja perawat. Untuk menyempurnakan variabel ini, sesuai dengan pernyataan pada kuisioner yaitu sebanyak 42 responden $(26,3 \%)$ menyatakan bahwa kepala ruangan harus selalu melakukan pengawasan saat perawat melakukan tindakan keperawatan di tiap unitnya (Nugraha, 2015). Hal ini dimaksudkan agar segala kegiatan dan tindakan yang dilakukan di unit terawasi dengan baik oleh supervisor maupun kepala ruangan di rumah sakit bahteramas. Kenyataan yang dihadapi di lapangan adalah pada tiap unit kepala ruangan merangkap sebagai supervisor ruangan, hal inilah yang menjadi salah satu penyebab dari tidak terawasinya tindakan asuhan keperawatan di rumah sakit Bahteramas Kota Kendari.

Kesimpulan dari variabel empirical quality result yaitu variabel ini dikategorikan sudah baik sebanyak $99,6 \%$, perlu di pertahankan dan perlu ditingkatkan pada kepala ruangan melakukan pengawasan saat melakukan tindakan asuhan keperawatan di tiap unitnya. 


\section{Hubungan lingkungan kerja secara simultan terhadap kepuasan kerja perawat \\ Berdasarkan analisis dengan judul} hubungan lingkungan kerja secara stimulan terhadap kepuasan kerja perawat ditemukan bahwa terdapat pengaruh yang signifikan dari lingkungan secara bersama-sama terhadap kepuasan kerja dengan nilai $\mathrm{p}=0,001<0,05$. Peran lingkungan kerja pada sector public menjelaskan bahwa menambah kepercayaan dan keyakinan perawat mengenai karakteristik pekerjaan tertentu dan konteks kerja dalam suatu lingkungan kerja yang pada umumnya terkait dengan sector public secara signifikan mempengaruhi kepuasan kerja karyawan (Holatila, 2020). hasil model ini menunjukkan bahwa organisasi public tertarik dalam meningkatkan kepuasan kerja karyawan sehingga harus mempertimbangkan kondisi lingkungan kerja yang dapat memengaruhi peprsepsi karyawan terhadap pekerjaannya (Holatila, 2020).

Data dari 137 rumah sakit di Pennsylvania dari 1999-2006 dianalisis oleh (You, Aiken and Sloane, 2013) dengan mengeksplorasi hasil keperawatan seperti ketidakpuasan dan omset terkait dengan perubahan dalam lingkungan praktik keperawatan dari ke waktu. Temuan menjelaskan bahwa hasil keperawatan ditingkatkan dari waktu kewaktu karena perbaikan di lingkungan praktik (Suryadi, 2013).

(Magesh and Chandrasekar, 2011) berpendapat bahwa organisasi sebaiknya memerhatikan menciptakan lingkungan kerja yang dapat meningkatkan kemampuan karyawan untuk lebih produktif dalam rangka meningkatkan keuntungan bagi organisasi. Anggapan lainnya adalah manusia untuk melakukan interaksi dan hubungan manusia yang memainkan peran lebih dominan dalam kepuasan kerja secara keseluruhan mementingkan keterampilan manajemen dibandingkan uang, waktu dan energi semua yang diperlukan untuk meningkatkan keseluruhan kinerja organisasi (Agus, 2017).

Pembahasan di atas dapat disimpulkan bahwa pentingnya organisasi mengidentifikasi kebutuhan karyawan mereka dan memuaskan mereka untuk memastikan pencapaian yang efektif pada sasaran dan tujuan melalui perbaikan kerja menjadi lebih baik, baik dari segi instrinsik maupun ekstrinsik. Pengelolaan tenaga kerja menjadi lebih sulit karnakaryawan sangat mampu menuntut kualitas yang tinggi dan sadar hak mereka saat bekerja di sebuah organisasi khususnya lingkungan kerja rumah sakit (Herman, 2016).

\section{KESIMPULAN}

Berdasarkan penelitian dan pembahsan mengenai determinan lingkungan kerja terhadap kepuasan kerja di RS Bahtermas Kota Kendari Tahun 2017 dapat disimpulkan bahwa: Transformational Leadership hal ini sangat terkait dengan kepuasan kerja para perawat, Structural Empowerment berhubungan secara bermakna dengan kepuasan kerja perawat, Examplary Professional Practice berhubungan secara bermakna dengan kepuasan kerja perawat, New Knowledge, Innovations and Improvement berhubungan bermakna dengan kepuasan kerja perawat, Empirical Quality Result berhubungan secara bermakna dengan kepuasan kerja perawat dan lingkungan kerja secara bersama-sama berhubungan secara bermakna dengan kepuasan kerja peraw at di RS Bahteramas Kota Kendari.

\section{UCAPAN TERIMA KASIH}

Tim penulis dan peneliti mengucapkan terima kasih kepada Kepala Rumah Sakit Bahteramas Provins Sulawesi Tenggara beserta jajarannya dan seluruh responden yang dilibatkan dalam penelitian ini, serta rekan rekan yang turut membatu selama penelitian ini di laksanakan.

\section{DAFTAR PUSTAKA}

Achmad Masfi (2018) 'Analisis Efektifitas Organisasi Dengan Pendekatan Model Mc Kinsey 7s Framework Terhadap Kinerja Puskesmas Di Kabupaten Sampang'.

Adam, R. A. (2013) 'Pengembangan Budaya Organisasi Keperawatan Untuk Meningkatkan Kinerja Dan Kepuasan Perawat Dalam Penerapan Metode Asuhan Keperawatan Profesional Di Rumah Sakit'.

Agung Ayu Indrasari Dewi (2017) 'Gambaran Tindakan Pemberian Obat Yang Benar Pada Pasien Rawat Inap Di Rsu Bahteramas Provinsi Sulawesi Tenggara'.

Agus, J. R. (2017) 'Pengaruh Kompetensi Dan Motivasi Terhadap Kepuasan Kerja Serta Implikasinya Pada Kinerja Pegawai Dinas Koperasi, Usaha Mikro, Kecil Dan 
Menengah Kota Bandung'.

Annisa, U. (2019) 'Peningkatan Kinerja Sebagai Dampak dari Kepemimpinan Transformasional secara Langsung dan Tidak Langsung serta Melalui Kepuasan Kerja dan Motivasi (Studi pada Guru Tetap SMA Islam Dian Didaktika)'.

Ayu, T. S. (2018) Pengaruh Kecerdasan Intelektual, Kecerdasan Emosional, dan Kecerdasan Spiritual Terhadap Kinerja Karyawan (Studi Kasus Pada Pondok Pesantren Darunnajah Jakarta). Jakarta: Fakultas Ekonomi dan Bisnis UIN Syarif Hidayatullah.

Baihaqi, M. F. and Suharnomo (2010) 'Pengaruh Gaya Kepemimpinan Terhadap Kepuasan Kerja Dan Kinerja Dengan Komitmen Organisasi Sebagai Variabel Intervening ( Studi Pada PT. Yudhistira Ghalia Indonesia Area Yogyakarta )'.

Baumann, L. (2007) 'Skin ageing and its treatment', Journal of Pathology. John Wiley \& Sons, Ltd, pp. 241-251. doi: 10.1002/path.2098.

Bawono, D. C. and Nugraheni, R. (2015) 'Analisis Pengaruh Pemberian Insentif, Kepemimpian Dan Beban Kerja Terhadap Kinerja Perawat (Studi pada Perawat ruang RSUD Kota Semarang)'.

Berliana, R. (2019) 'Tinjauan Sistem Manajemen K3 Dalam Mendukung Pencapaian Akreditasi Rumah Sakit (Studi Kasus di RSIA X Kota Semarang)'.

Chasanah, N. (2008) 'Analisis Pengaruh Empowerment, Self Efficacy Dan Budaya Organisasi Terhadap Kepuasan Kerja Dalam Meningkatkan Kinerja Karyawan (Studi Empiris pada Karyawan PT. Mayora Tbk Regional Jateng dan DIY)'.

Devi, N. M. B. S. (2017) 'Analisis Pegawai Tetap dan Pegawai Outsourcing Ditinjau Dari Pemberdayaan, Kepuasan Kerja, dan Komitmen Organisasional Pada PT. Angkasa Pura I (Persero) Bandar Udara Juanda Surabaya'.

Diviani, G. M. and Djastuti, I. (2015) 'Analisis Pengaruh Insentif Terhadap Kinerja Karyawan Dengan Kepuasan Kerja Sebagai Variabel Mediasi (Studi Pada Karyawan Perusahaan Air Minum Kabupaten Jepara)'.

Fayzhall, M., Asbari, M. and Purwanto (2020)
Transformational versus Transactional Leadership: Manakah yang Mempengaruhi Kepuasan Kerja Guru?, EduPsyCouns: Journal of Education, Psychology and Counseling.

Ghina, M. S. (2021) 'Peran Lingkungan Kerja Dan Fasilitas Kerja Dalam Meningkatkan Kinerja Karyawan Lpp Stasiun Tvri Lampung'.

Hariandja; Arief, S. and Kautsar, W. (2007) Strategi Perusahaan Dalam Pengembangan Produk Baru: Penelitian Kasus Perusahaan Manufaktur Di Indonesia.

Hasmoko, E. V. (2008) 'Analisis Faktor-Faktor Yang Mempengaruhikinerja Klinis Perawat Berdasarkan Penerapansistem Pengembangan Manajemen Kinerja Klinis(Spmkk) Di Ruang Rawat Inaprumah Sakit Panti Wilasa Citarum Semarangtahun 2008 (Analysis of the Factors Influencing Nurseâ $\square \square^{\mathrm{TM}_{\mathrm{S}}}$ Clinical Work Performance Based onImplementing the Management Development System of Clinical WorkPerformance at Inpatient Room of Panti Wilasa Citarum Hospital, Semarang)'.

Herman, I. (2016) 'Analisis Lingkungan Kerja Dan Kepuasan Kerja Tenaga Paramedis Dalam Rangka Meningkatkan Kualitas Pelayanan Rumah Sakit Ahmad Yani Pekanbaru-Riau'.

Holatila, G. E. (2020) 'Pengaruh Audit Manajemen Terhadap Perilaku Karyawan Pada Pt Bank Negara Indonrsia(Persero)Tbk. Kantor Cabang Makassar'.

Ilyas, M. (2015) Metodologi Penelitian Pendidikan Matematika, Pustaka Ramadhan. Available at: http://repository.uncp.ac.id/22/ (Accessed: 2 June 2021).

Kurnia, Y. (2021) 'Seminar Hasil Penelitian Dan Pengabdian Masyarakat Untuk Peningkatan Mutu Pendidikan Dan Pelayanan Kepada Masyarakat', adoc.pub.

Kwak, C. and Chung (2010) 'Relationship of job satisfaction with perceived organizational support and quality of care among South Korean nurses: A questionnaire survey', International Journal of Nursing Studies. Pergamon, 47(10), pp. 1292-1298. doi: 
10.1016/j.ijnurstu.2010.02.014.

Lamidi (2009) 'Pengaruh Kepemimpinan Transformasional Terhadap Komitmen Organisasional Dengan Variabel Moderating Kepuasan Kerja Pegawai Rumah Sakit Swasta Di Pku Muhammadiyah Surakarta', Jurnal Ekonomi dan Kewirausahaan, 9(1), pp. $12-22$.

Lodjo, F. S. (2013) 'Pengaruh Pelatihan, Pemberdayaan Dan Efikasi Diri Terhadap Kepuasan Kerja', Jurnal Riset Ekonomi, Manajemen, Bisnis dan Akuntansi, 1(3), pp. 747-755. doi: 10.35794/emba.vli3.1882.

Magesh, N. S. and Chandrasekar (2011) 'Morphometric evaluation of Papanasam and Manimuthar watersheds, parts of Western Ghats, Tirunelveli district, Tamil Nadu, India: A GIS approach', Environmental Earth Sciences. Springer, 64(2), pp. 373-381. doi: 10.1007/s12665-010-0860-4.

Mardhiah Afrini, I. K. (2017) Analisis Kualitas Layanan Menggunakan Metode Quality Function Deployment (Qfd) Dan Service Blueprint Pada Instalasi Rawat Jalan Rsud Bahteramas Provinsi Sulawesi Tenggara Analysis Of Service Quality Using Quality Function Deployment (Qfd) And Service Blueprint Methods On Outpatient Installation In Rsud BahteramasProvinsi Sulawesi Tenggara. Maria (2020) 'Faktor Motivasi Perawat Spk (Sekolah Perawat Kesehatan) Melanjutkan Pendidikan Diiikeperawatan Pada Mahasiswa Rpl (Rekognisi Pembelajaran Lampau) Di Poltekes Kemenkes Kupang.'

Mayasari, A. (2009) 'Analisis Pengaruh Persepsi Faktor Manajemenkeperawatan Terhadap Tingkat Kepuasankerja Perawat Di Ruang Rawat Inap Rsud Kotasemarang'.

Mukhtari, B. Al (no date) 'Kepuasan pelanggan pelayanan rawat jalan Rumah sakit umum daerah Dr muwardi Surakarta', digilib.uns.ac.id.

Nasution, (Muhammad) (2017) 'Pengaruh Stres Kerja, Kepuasan Kerja Dan Komitmen Organisasi Terhadap Turnover Intention Medical Representative', Mix: Jurnal Ilmiah Manajemen, 7(3), p. 224238. doi: 10.22441/jurnal_mix.

Niar Rahmawati, P., Hasmia Naningsih, P. 1 and Wahida, P. 2 (2017) 'Hubungan Ketuban Pecah Dini Dengan Kejadianasfiksia Pada Bayi Baru Lahir Di Rsu Bahteramaskota Kendari Provinsi Sulawesi Tenggara Tahun 2016'.

Nugraha, D. A. (2015) Institutional Repository UIN Syarif Hidayatullah Jakarta: Komunikasi antarpribadi perawat terhadap pasien skizofrenia dalam proses peningkatan kesadaran di rumah sakit jiwa Dr. H. Marzoeki Mahdi Bogor, Institutional Repository UIN Syarif Hidayatullah Jakarta.

La ode Muhammad Yasmin (2020) 'FaktorFaktor Yang Berhubungan Dengan Kinerja Petugas Kesehatan Pada Ruang Kelas I Di Rumah Sakit Bahteramas Kota Kendari Factors That Are Related to The Performance of Health Officers In Class I Room In Bahteramas Hospital, Kendari City', MIRACLE Journal of Public Health. Universitas Mandala Waluya, 3(2), pp. 142-152.

Pabidang, S. (2017) 'Pengaruh Kualitas Layanan Dokter Dalam Sistem Bpjs Kesehatan Terhadap Kepuasan Pasien Bpjs Kesehatan Di Rumah Sakit Umum Daerah Dr. H. Slamet Martodirdjo Pamekasan Dan Puskesmas SeKabupaten Pamekasan'.

Prakarsa, G. (2017) 'Analisis kepemimpinan spiritual terhadap kinerja perawat melalui kepuasan kerja: Studi kasus pada RSI Siti Khadijah Palembang'.

Priadi, H. (2021) 'PEngaruh Kepemimpinan Transformasional, Lingkungan Kerja Non Fisik, Beban Kerja Dan Stres Kerja Terhadap Kinerja Pegawai Pada Bank Bni Kota TegaL'.

Pribadi, A. (2009) 'Analisis Pengaruh Faktor Pengetahuan, Motivasi,Dan Persepsi Perawat Tentang Supervisikepala Ruang Terhadap Pelaksanaan Dokumentasiasuhan Keperawatan Di Ruang Rawat Inap Rsudkelet Provinsi Jawa Tengah Di Jepara'.

PURNOMO, M. L. S. (2016) 'Faktor Yang Mempengaruhi Ketidakpatuhan Wajib Pajak Pekerja Bebas yang Terdaftar di KPP Pratama Gresik Utara'.

Putri, F. K. (2009) Aplikasi Quality Function Deployment dalam TRIZ ( Theory of Inventive Problem Solving ) pada Peningkatan Kualitas Jasa.

Rudyanto, R. (2012) 'Pengaruh Organizational 
Citizenship Behavior Pada Kualitas Layanan, Kepuasan Pelayanan dan Kinerja', pp. 1-125.

Sanjaya, E. P. (2012) 'Pelaksanaan Fungsi Sosial Rumah Sakit Berdasarkan Undang-Undang Nomor 44 Tahun 2009 Tentang Rumah Sakit (Studi Kasus Rumah Sakit Panti Wilasa Citarum Semarang)'.

Sari, S. I. P. (2019) 'Motivasi Terhadap Kinerja Perawat Rumah Sakit Daerah Balung Jember Melalui Kepuasan Kerja Sebagai Variabel Intervening, repository.unej.ac.id. Available at: https://repository.unej.ac.id/handle/1234 56789/94990 (Accessed: 2 June 2021).

Set Xaverius Tumbelaka, S. (2016) Pengaruh Budaya Organisasi Terhadap Kepuasan Kerja, Komitmen Organisasional Dan Intention To Leave (Studi pada Karyawan PT.Bitung Mina Utama), Jurnal Bisnis dan Manajemen. doi: 10.26905/JBM.V3I1.78.

Setiawan, B. A. dan A. M. (2013) 'Transformational Leadership - Ilustrasi di Bidang Organisasi Pendidikan', Ilustrasi di Bidang Organisasi Pendidikan.

Sureskiarti, E. and Brillianty, G. D. (2017) Hubungan Kinerja Perawat Dengan Kepuasan Kerja Perawat Di Ruang Rawat Inap Rumah Sakit Umum Daerah Ince Abdul Moeis Samarinda Tahun 2017, Jurnal Husada Mahakam. doi: 10.35963/HMJK. V4I4.93.

Suryadi, R. F. (2013) Hubungan Peran Educator Perawat Dalam Discharge Planning Dengan Tingkat Kepatuhan Pasien Rawat Inap Untuk Kontrol Di Rumah Sakit Paru Kabupaten Jember.

Susanti, A. I. (2012) Kualitas Pelayanan Prima Program Pemeliharaan Kesehatan Masyarakat Surakarta (PKMS) Di Puskesmas Sibela Mojosongo Kecamatan Jebres Kota Surakarta.

Tahsinia, N. (2015) "Faktor-Faktor yang Berhubungan dengan Kepuasan Kerja Perawat di RS. Rumah Sehat Terpadu, Parung, Bogor, Tahun 2013.

Tawakkal, Fajar Kurniawan, I. I. (2020) Studi Pelaksanaan Selfmedication Pada Penderita Diare Berdasarkan Tingkat Pengetahuan Masyarakat Pesisir Kecamatan Soropia Kabupaten Konawe, Jurnal Aksara Public..
Warsito, B. E. (2006) 'Pengaruh Persepsi Perawat Pelaksanatentang Fungsi Manajerial Kepala Ruangterhadap Pelaksanaan Manajemen Asuhankeperawatan Di Ruang Rawat Inap Rsjddr. Amino Gondohutomo Semarang'.

Wuryanto, E. (2012) Hubuiigai \{Aiitara Kuatita\$ Kemimpii\{Ail Dal\{ Gaya Mailajeme\}I Deilgaii Kepuasa]I Kerja Perawat Di Rumah Sakit Umum Daera\} I Tugurejo Semaraiig, FIKkeS.

Yosephus, A. (2012) 'Motivasi kerja dan Pengembangan Karir Perawat di ruang Instalasi Gawat DaruratRSUD. Prof. DR. W.Z. Johannes Kupang.'

You, L. ming, Aiken, L. H. and Sloane, D. M. (2013) 'Hospital nursing, care quality, and patient satisfaction: Cross-sectional surveys of nurses and patients in hospitals in China and Europe', International Journal of Nursing Studies. Pergamon, 50(2), pp. 154-161. doi: 10.1016/j.ijnurstu.2012.05.003.

Yunda, P. N. A. (2019) 'Mediasi Komitmen Organisasi Pada Pengaruh Kepuasankerja Terhadap Organizational Citizenship Behavior (Ocb) Perawat Rsu Pku Muhammadiyah Bantul'.

Zendrato, M. V. and Sri Hariyati, R. T. (2018) 'Optimalisasi Pengelolaan Asuhan Keperawatan di Instalasi Rawat Jalan Rumah Sakit X', Jurnal Persatuan Perawat Nasional Indonesia (JPPNI), 2(2), p. 85. doi: 10.32419/jppni.v2i2.86. 